\title{
The Effect of Systematic Risk (Beta) on Stock Prices with Interest Rates and Curses as Moderation Variables
}

\author{
Alfiani Rofiqoh ${ }^{1}$, Zaim Mukaffi ${ }^{2, *}$ \\ ${ }^{1,2}$ Faculty of Economics, Universitas Islam Negeri Maulana Malik Ibrahim, \\ Zip Code 65144, Jl. Gajayana no. 50 Malang-East Jawa-Indonesia \\ *Corresponding authorEmail: zaim@manajemen.uin-malang.ac.id
}

\begin{abstract}
This study aims to determine the effect of systematic risk (beta) on stock prices and find out whether interest rates and exchange rates can be used as moderating variables on the relationship of systematic risk to stock prices. The population in this study is the banking sub-sector companies included in the IDX 2014-2017. The research sample was taken by purposive sampling technique, which amounted to 24 companies. Data analysis method used is descriptive analysis, and data analysis was used that technique Last Squares Dummy Variable (ISDV) and Moderate Regression Analysis (MRA). The results show that systematic risk (beta) ha s a positive and significant effect on stock prices. Interest rates and exchange rates are significantly able to moderate the relationship between systematic risk (beta) and stock prices. the systematic risk represented by beta stocks can directly influence changes in stock prices. Exchange rates cannot strengthen the effect of systematic risk on stock prices but instead weaken the effect of systematic risk on stock prices which means that the exchange rate cannot affect changes in stock prices. Study constribute to the discussion about determine the effect of systematic risk, special beta that's influenced by stock price, interest and exchange rates.
\end{abstract}

Keywords: beta, stock price, interest rate, and exchange rate

\section{INTRODUCTION}

Stock is one of the securities in the capital market which is known to have a variety of potential returns that attract investors to prefer to invest in stocks rather than saving money in the bank in the hope that the deposit interest rate will be obtained. Whereas if the investor invests in the retun stock obtained, it consists of two components, namely yield (return that comes from the distribution of stock dividends) and capital again (the price difference when buying and selling shares) [1]. it looks more profitable but behind the high retun there is a high risk too, because the relationship retun and risk are linear, which means the greater the risk borne the greater the expected return [1]. So that this raises unique phenomena in stocks, one of which is the fluctuation of stock prices.

Stock prices are a reflection of investor expectations of income factors, cash flow, and the rate of return required by investors, which are the three factors that are also strongly influenced by macroeconomic performance [1]. This macroeconomic performance affects the performance of all companies. If the macroeconomic performance is unstable, it can have a negative impact on all companies, including the banking sub-sector, which will also feel the impact. This macroeconomic uncertainty is called market risk.

Market risk is also called systematic risk. Systematic risk is a risk that cannot be eliminated by diversification (undiversifiable), because this risk fluctuation is influenced by macro factors that can affect the market as a whole [2]. The magnitude of systematic risk can be measured by a systematic risk index which is often referred to as stock beta. Stock beta index shows the sensitivity level of a stock to general market conditions. Beta index is determined by comparing the level of risk owned by a stock to the risk of all listed shares [3]. Seen from the previous explanation, it can be concluded that 
systematic risk can influence the decision of investors to buy shares which can affect the amount stock demand which results in fluctuations in stock price movements. where suitable.

\section{LITERATUR REVIEW}

\subsection{Stock Prices}

Stock prices are a reflection of investor expectations of income factors, cash flow, and the level of return required by investors, which are also highly influenced by macroeconomic performance [1]. The price of shares in trading on the IDX is the impact of the demand (supply) and supply (demand) from investors [4].

Valuation of ordinary shares can be divided into three as follows [2]:

1) Book value per sheet of ordinary shares is the value of economic net worth divided by the number of shares of common stock outstanding. Economic net worth is the difference between total assets and total liabilities.

2) While the market price is the price formed in the stock trading market.

3) Intrinsic value is the value of shares that should occur.

To predict changes in the capital market, there are two things that can be used as forecasting markets, namely the use of data on economic cyclical changes and the use of data on changes in several macroeconomic variables [1]:

\section{1) Economic cyclical changes}

Changes in stock prices will reflect the cyclical changes in the economy that happened. Investors should try to learn from the patterns of changes that have occurred as a determination to decide to buy or sell stocks in accordance with the expectations of economic cyclical changes that are likely to occur. If the economic cycle is predicted to improve, then the stock price approaching the economic cyclical turning point (before reaching the low point) will improve ahead of the improving economic cycle.

2) Changes in macroeconomic variables

Observations on changes in several variables or macroeconomic indicators such as interest rates, GDP, inflation, or currency exchange rates, are believed to help investors to predict what will happen to capital market changes.

\subsection{Systematic Risk (Beta)}

Systematic risk that can be referred to as market risk, and some call it general risk (general risk), is the risk associated with changes that occur in the market as a whole. These changes can then affect the variability of returns on an investment. Systematic risk can be measured using stock beta.

Beta is a risk measurement tool affected by macroeconomic events as the sensitivity of stock returns to fluctuations in portfolio returns. Meanwhile, Beta is a tool to measure the rate of movement of existing stock returns on stock markets[5],[6]. Beta is a CAPM key. Beta measures the relative changes in stocks to the average stock, which by definition has $\beta=1.0$ and the stock beta can be seen from the slope of the regression coefficient of individual returns to market returns.

Stock market risk is measured by the beta coefficient, which is an index of the relative volatility of stocks [6]. Benchmarks or beta benchmarks are as follows:

$\beta>0$ : That is, if the beta value is 0.5 then the level of stock returns will be greater than half of the market return.

$\beta=1$ : That is, if the movement of market returns moves up 5 levels then the stock return will also move up 5 levels as well if the market returns down 2 then the stock return will also go down 2 .

$\beta<0$ : It means, if the market return decreases, the stock return will actually increase.

Measuring beta using a single index model can be calculated by the equation [1]:

$\mathrm{R}_{\mathrm{i}}=\alpha_{\mathrm{i}}+\beta \mathrm{i} \mathrm{R}_{\mathrm{M}}+\mathrm{e}_{\mathrm{i}}$

Where:

$\mathrm{R}_{\mathrm{i}} \quad=$ return of securities $\mathrm{i}$.

$\mathrm{R}_{\mathrm{M}} \quad=$ market index return.

$\alpha_{\mathrm{i}}=$ part of security return $\mathrm{i}$ that is not influenced by market performance

$\beta_{\mathrm{i}}=$ measure of the sensitivity of the return security $i$ to changes market return.

$\mathrm{e}_{\mathrm{i}} \quad=$ residual error

If risk is associated with investor preferences, investor preferences for risk are divided into three types [2], namely:

1) Investors who like risk seekers

2) Investors who are risk neutral

3) Investors who do not like and avoid risk (risk averter)

\subsection{Interest Rates}

The BI Rate is an interest rate policy that reflects the stance or monetary policy stance set by Bank Indonesia and is announced to the public (www.bi.go.id). The real interest rate, which is the interest rate after adjusting for the expected inflation rate. In addition to influencing consumption and investment spending, the real interest 
rate has major implications for the welfare of the debtor and creditor because it influences the way in which real wealth is distributed among them. The real interest rate also affects the exchange rate (exchange rate) in the international market. If other factors are fixed, an increase in the real interest rate in the country will attract funds from abroad, thereby raising the value of the domestic currency in the eyes of foreigners, and vice versa foreign goods will be cheaper on the domestic market [7].

If interest rates fall, investors will tend to invest their money in mutual funds or the stock market because they expect to get more returns than just saving their money in the bank. In addition, a decrease in interest rates will lead to lower borrowing interest costs thereby creating an expansion and increase in net profit. In the long run, an increase in net profit can cause the stock market price to increase. Meanwhile, when interest rates rise, it causes a decrease in stock prices, because investors will tend to save their money and get a return from the bank interest they get [7].

\subsection{Exchange Rates}

Foreign currency or what is usually abbreviated as "Forex" is freely interpreted as the currency issued and used as a legal tender in other countries. Thus, a currency is called foreign currency if it originates from another country. For residents in countries that are not countries of origin, the currency will be referred to as foreign exchange or foreign exchange. More broadly, foreign exchange can also be interpreted as all obligations towards foreign currencies paid overseas, both in the form of deposits in foreign banks and obligations in foreign currencies [8].

Based on history and development, the exchange rate system that has existed and is being practiced is as follows [9]:

\section{1) Fixed exchange rate system (FIER)}

The fixed exchange rate system equalized by an international financial institution (IMF) or by each country in accordance with its economic capabilities (usually based on the value of hard currency) is a system of exchange rates that fixes the value of foreign exchange rates against the currency of the country concerned with a certain value which is the same as a certain period (not affected by changes in uncertain economic conditions).

\section{2) Floating exchange rate (FER) system}

This exchange rate system determines that the value of a country's currency is determined by the strength of demand and supply in the (official) money market. This system is divided into two types namely clean float (pure float) is the determination of the exchange rate without government intervention. Whereas if the government participates in influencing the value of the exchange rate, it is dirty float, government intervention usually directly enters the money market with quantitative monetary policy and fiscal policy; or indirect nature such as appeals and such.

\section{3) Pegged exchange rate system (PER)}

In this system the exchange rate is associated with the value of another country's currency, or a certain number of currencies. If the two exchange rate systems described above are the last highest exchange rates, the PER system uses the middle exchange rate of a particular currency that requires more or less than the middle rate of $2.5 \%$.

\subsection{Hypothesis}

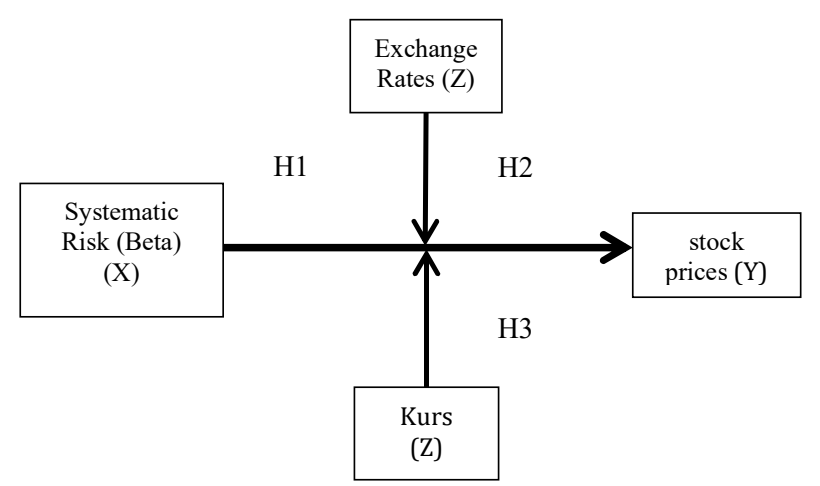

Research Hypothesis

H1 : Systematic Risk has a significant positive effect on stock prices.

$\mathrm{H} 2$ : Interest rates can strengthen the effect of systematic risk on stock prices.

H3 : Exchange rates can strengthen the effect of systematic risk on stock prices

\section{METHODS}

Based on the type of data this research is categorized as quantitative research. And the approach used is a descriptive approach. The population in this study were banking sub-sector companies listed on the Stock Exchange during the 2014-2017 research period. Sampling is done by purposife sampling technique with the following criteria: (1) Banking sub-sector companies that are included in the IDX for the period 2014-2017; (2) The banking subsector company that consistently joins the Indonesia Stock Exchange during the research period, from January 2014 to December 2017; (3) Companies that always have stock price movements every month; (4) Companies that have stock returns every month. The results show a total sample of 24 companies. 


\subsection{Data source}

The data collected in this study is done by the documentation method, which is the technique of collecting data from documents. Data used from the Indonesia Stock Exchange www.idx.co.id, BI website (www.bi.go.id) and (www.pusatdata.kontan.co.id) for the period 2014-2017. Also collects some information through books, Economics and Business journals, previous research and other literature related to research.

\subsection{Data analysis technique}

Quantitative analysis is a method of analysis using numbers that can be calculated to estimate the magnitude of the effect of one change or several events. The statistical analysis tool of the study used eviews. 10 student version software because researchers used panel data types, namely a combination of cross section and time series data.

\subsection{Data processing}

Panel data estimation has three techniques that can be used, namely the common effect model using the least squares technique or OLS (Ordinary Last Square), then the fixed effect model that uses dummy variable techniques or LSDV (Last Square Dummy Variable), or random effect models where intercept differences accommodated by the error terms of each object, also called the Error Component Model (ECM) or Generalized Last Square (GLS) technique. Of the three models of the approach, the most suitable one will be chosen. The selection of the best approach model is done by the Chow Test to determine between common effects or fixed effects, the Hausman Test to determine between fixed effects or random effects, and the Lagrange Multiplier Test to determine between common effects or random effects.

\section{RESULT}

The purpose of this study is to test and analyze the effect of systematic risk on beta with interest rates and the exchange rate as a moderating variable. The variables in this study are divided into three types, namely the dependent variable used is stock price, the independent variable used is systematic risk as measured by beta, and the moderating variable used is the interest rate and exchange rate.

\subsection{Model Analysis and Hypothesis Testing}

\subsubsection{Selection of Estimation Model}

In order to know the most suitable estimation method, Chow Test is conducted to find out which is the best between the Common Effect or Fixed Effect. Common Effect is accepted when the probability of chisquare cross-section is greater than 0.05. Fixed Effec is accepted when the probability of chi-square crosssection is smaller than 0.05. From table 1, the test results show that the probability value of the Chi-Square cross-section is 0,000 less than the significance value (5\%). So that $\mathrm{H} 0$ is rejected and $\mathrm{H} 1$ is accepted which means the best estimation model is Fixed Effect.

Then do the Hausman test to find out which one is the most suitable between Fixed Effect or Random Effect. Fixed effects are accepted when a random probability cross-section value is smaller than 0.05 . Random effects are accepted when the random probability cross-section value is greater than 0.05 . From table 2, the test results show that the probability value of a random cross-section is 0.00135 less than the significance value $(5 \%)$. So H0 is accepted and $\mathrm{H} 1$ is rejected which means the best estimation model is Fixed Effect.

Based on Chow Test and Hausman Test shows that the best estimation model is Fixed Effect, then for Lagrange Multiplier Test is not done and Fixed Effect is the best estimation model to analyze the effect of systematic risk on stock prices in the banking sub-sector companies listed on the Stock Exchange in 2014- 2017. The results of processing data using Fixed Effect are shown in Table 3.

From table 3 the test results show that the R-square value is 0.944622 or $94.4622 \%$. This means that the share price variable can be explained by beta variables, interest rates, and exchange rates of $94.4622 \%$. While the remaining $5.5378 \%$ is explained by other independent variables that are not assumed in the study.

Table 1. Chow Test Results

\begin{tabular}{lrrr} 
Redundant Fixed Effects Tests & & & \\
Pool: BANK \\
Test cross-section fixed effects \\
\hline \hline Effects Test & Statistic & d.f. & Prob. \\
\hline \hline Cross-section F & 701.912414 & $(23,1127)$ & 0.0000 \\
Cross-section Chi-square & 3144.347966 & 23 & 0.0000 \\
\hline
\end{tabular}

Table 2. Hausman Test Results

\begin{tabular}{|c|c|c|c|}
\hline Test Summary & Chi-Sq. Statistic & Chi-Sq. d.f. & Prob. \\
\hline Cross-section random & 6.101173 & 1 & 0.0135 \\
\hline
\end{tabular}


Table 3. Fixed Effect Test Results

\begin{tabular}{|c|c|c|c|c|}
\hline Variable & Coefficient & Std. Error & t-Statistic & Prob. \\
\hline C & 6.860268 & 0.012038 & 569.9054 & 0.0000 \\
\hline BETA & 0.061732 & 0.012060 & 5.118653 & 0.0000 \\
\hline \multicolumn{5}{|c|}{ Effects Specification } \\
\hline \multicolumn{5}{|c|}{ Cross-section fixed (dummy variables) } \\
\hline R-squared & 0.944622 & \multicolumn{2}{|c|}{ Mean dependent var } & 6.836278 \\
\hline Adjusted R-squared & 0.943132 & \multicolumn{2}{|c|}{ S.D. dependent var } & 1.407966 \\
\hline S.E. of regression & 0.335757 & \multicolumn{2}{|c|}{ Akaike info criterion } & 0.682028 \\
\hline Sum squared resid & 100.5578 & \multicolumn{2}{|c|}{ Schwarz criterion } & 0.813464 \\
\hline Log likelihood & -287.7096 & \multirow{2}{*}{\multicolumn{2}{|c|}{$\begin{array}{l}\text { Hannan-Quinn criter. } \\
\text { Durbin-Watson stat }\end{array}$}} & 0.732192 \\
\hline F-statistic & 633.9810 & & & 0.162072 \\
\hline Prob(F-statistic) & 0.000000 & & & \\
\hline
\end{tabular}

\subsubsection{Hypothesis testing}

Based on the test results in table 3, the researcher can prove hypothesis 1 , namely the effect of systematic risk on stock prices where the t-statistic value shows the partial effect of independent variables separately (beta) on the dependent variable (stock price) in the panel data regression model. The regression test results show that the beta regression coefficient is 0.061732 with a standard error of 0.012060 and a t-statistic value of 5.118653 with a probability value of 0.0000 smaller than the expected significance level $(0.0050<0,05)$. So that beta has a positive and significant influence on stock prices in the banking sub-sector companies for the period 2014-2017, then H1 is accepted. Systematic Risk has a significant positive effect on stock prices.

\subsubsection{MRA Testing}

MRA testing (Moderated Regression Analysis) is a test model to find out that moderating variables can strengthen or even weaken the influence of the independent variables (beta) on the dependent variable (stock price). The following are the results of the moderation test:

\section{1) Variable Moderation of Interest Rates}

Based on the results of the moderation test with variable modesari (beta times the interest rate) shows that the t-statistic value of the moderating variable is 6.281820 and the moderation probability is 0.000 , this value is smaller than the expected significance level $(0.000<0.05)$. The test results show that the interest rate variable (moderating variable) interacts with the beta variable (independent variable) and also has a significant relationship with the stock price variable (dependent variable) so that it can be seen that the interest rate variable is the quasi moderator variable. The value of R-square 0.947106 is greater than before 0.944622 which means that the variable interest rate can strengthen the systematic risk relationship to stock rights. Then $\mathrm{H} 2$ is accepted. Interest rates can strengthen the effect of systematic risk on stock prices.
Table 4: Variable MRA Test Results for Interest Rates

Dependent Variable: HARGASAHAM

Method: Panel Least Squares

Date: 09/06/18 Time: 10:16

Sample: 2014M01 2017M12

Periods included: 48

Cross-sections included: 24

Total panel (balanced) observations: 1152

\begin{tabular}{crrrr}
\hline \hline Variable & Coefficient & Std. Error & t-Statistic & Prob. \\
\hline \hline BETA & 578.6395 & 98.91051 & 5.850132 & 0.0000 \\
SUKUBUNGA & -14596.69 & 1960.751 & -7.444441 & 0.0000 \\
C & 2992.212 & 122.9974 & 24.32744 & 0.0000 \\
BETA*SUKUBUNGA & -10942.85 & 1741.988 & -6.281820 & 0.0000 \\
\hline \hline \multicolumn{5}{c}{ Effects Specification } \\
\hline \hline
\end{tabular}

Cross-section fixed (dummy variables)

0.947106 Mean dependent var

2006.060

Adjusted R-squared

0.945883 S.D. dependent var

747.2404 Akaike info criterion

$6.28 \mathrm{E}+08$ Schwarz criterion

S.E. of regression

Sum squared resic

$\begin{aligned} 6.28 \mathrm{E}+08 & \text { Schwarz criterion } \\ -9243.034 & \text { Hannan-Quinn criter. }\end{aligned}$

-9243.034
774.7649 Dannan-Quinn criter.

3212.144

16.09381

Log likelihood

Prob(F-statistic) 0.000000

\section{2) Variable Exchange Rate Moderation}

Based on the results of the moderation test with the moderating variable (beta multiplied by the exchange rate), the t-statistic value of the moderating variable is 3.060578 and the moderation probability is 0.023 , this value is smaller than the expected significance level $(0.023<0.05)$. shows that the exchange rate variable (moderating variable) interacts with the beta variable (independent variable) and also has a significant relationship with the stock price variable (dependent variable) so that it can be seen that the exchange rate variable is the quasi moderator variable (pseudo moderator). The value of R-square 0.938567 is smaller than before 0.944622 which means that the variable interest rate can weaken the relationship of systematic risk to stock rights. Then $\mathrm{H} 3$ is accepted. Exchange rates can weaken the effect of systematic risk on stock prices.

Table 5: Variable MRA Test Results for Interest Rates

Dependent Variable: HARGASAHAM

Method: Panel Least Squares

Date: 09/06/18 Time: 10:17

Pample: 2014M01 2017

Periods included: 48

Cross-sections included: 24
Total panel (balanced) observations: 1152

\begin{tabular}{crrrr}
\hline \hline Variable & Coefficient & Std. Error & t-Statistic & Prob. \\
\hline \hline BETA & -1604.454 & 522.4804 & -3.070841 & 0.0022 \\
KURS & 0.063002 & 0.041830 & 1.506143 & 0.1323 \\
C & 1209.465 & 543.8088 & 2.224063 & 0.0263 \\
BETA ${ }^{*}$ KURS & 0.122189 & 0.039924 & 3.060578 & 0.0023 \\
\hline \hline
\end{tabular}

Effects Specification

Cross-section fixed (dummy variables)

R-squared

Adjusted R-squared

Adjusted R-square

Sum squared resid

0.938567 Mean dependent var

Sum squared resic

0.937147 S.D. dependent var

805.2996 Akaike info criterio

$\begin{array}{ll}\text { 7.30E+08 } & \text { Schwarz criterion } \\ -9329.235 & \text { Hannan-Quinn criter }\end{array}$

(atistic

-9329.235
661.0623
0.000000

0.000000 


\section{DISCUSSION}

\subsection{Systematic (Beta) Effect on Stock Prices}

The first hypothesis proves that systematic risk represented by beta has a significant effect on stock prices. So, if the greater the systematic risk of a stock it will be as high as the stock price. This is consistent with the statement that the capital market reflects what is happening in the macro economy because the investment value is determined by the expected cash flow and the return that the investor hints at, and both factors are influenced by changes in the macroeconomic environment. Thus, if we estimate cash flow, interest, or risk premium in order to find out the value of shares of a security, we must consider macro economic analysis, one of which is by analyzing systematic risk [1].

The results of this study are in line with the research conducted which states that systematic risk that is measured using beta has an effect on stock prices, this is because investors want to take greater risks in order to get a large stock return [10]. This research conducted that the greater the systematic risk, the more returns required by investors, with high returns make investors interested in investing so as to increase the price of their shares [11]. Systematic risk as measured by beta has no significant effect on stock prices. This is because systematic risk is beyond the control of the company so investors do not consider systematic risk as one of the reasons for choosing investmen [12]

One of the systematic risk factors influencing changes in the share price of the banking sub-sector is the Indonesian economy that was less stable in the study period due to the normalization of US monetary policy, the decline in the rupiah against the dollar, changes in interest rates, inflation, and other macroeconomic problems.

The lack of stability in the Indonesian economy in 2014 according to the Simanan Guarantee Agency (LPS) in the Quarterly 2014 Report on Stability and Banking Systems Analysis was due to increased consumption of high fuel oil, a weakening global economy and falling commodity prices, as well as the high role of foreign investors which makes the flow of return on investment large. In 2015 Indonesia's economic growth in general experienced improvement despite a decline in the rupiah exchange rate in the third quarter. In 2016 banking stock prices were not much different from the previous year, this was because Indonesia's economic conditions were not in a bad condition even though Indonesia's economic growth was not optimal. In 2017, the inflation rate has controlled Bank Indonesia (BI) to conduct monetary easing and reduce interest rates which are expected to increase credit demand. Stock prices serve as an illustration to measure banking performance. The higher the share price, the better the performance in managing assets owned to get a large profit so that it can provide a large investment return to investors.

For investors who dare to take big risks to get abnormal stock returns can invest in banking sub-sector companies because of the results of research that shows that systematic risk can affect changes in stock prices positively, the banking subsector that has a high beta value can be selected as a place to invest. Whereas for risk-neutral investors, it is still possible to consider banking as a place to invest because if seen during the year, research on banking stock prices continues to increase. However, for investors who are reluctant to take big risks, it is better to make banking at the end to be used as an investment choice because banks have a considerable risk.

\subsection{Effect of Interest Rate Moderation Variables on the Relationship of Systematic Risk to Stock Prices.}

Based on the results of the study indicate that the interest rate variable is a quasi moderation variable that can significantly strengthen the relationship of systematic risk to stock prices in the banking sub-sector for the period 2014-2017. The influence of interest rates on the relationship between systematic risk and stock prices is that the reduction in interest rates will reduce the interest costs of loans to reduce the expansion and increase in net income. In the short term, the increase in net income can increase stock market prices. While when interest rates rise, it causes a decline in stock prices, because investors will tend to save money and get a return from the bank interest that they get [7].

On the other hand, the rise of the Indonesian Interest Rate (SBI) will result in an increase in lending rates so that it can reduce banking net income which causes the level of risk in banks to rise. Rising risks to banks make investors expect an increase in banking stock returns. High returns make risk seekers (investors who dare to take risks) increasingly interested in investing and if in general banking investors are risk seekers, the high risk can be used as an excuse to encourage the movement of banking stock prices. This is consistent with the results of research conducted that systematic risk can significantly influence stock price changes due to the attitude of investors as risk seers who dare to take high risks by expecting a large investment return [13], [10], [12].

Interest rates can strengthen the relationship of systematic risk to stock prices. So that interest rates can be used as a benchmark for deciding investments. The relationship between interest rates and stock prices is negative, so if the interest rate falls then the stock price will rise. For investors who want to invest in banks in addition to paying attention to the amount of systematic 
risk, you should also pay attention to the movement of interest rates.

\subsection{Influence of Variable Moderation of Exchange Rate on weakening the relationship of systematic risk to stock prices.}

Based on the results of the study indicate that the exchange rate variable is a quasi moderator variable capable of weakening the relationship of systematic risk to stock prices. In other words, the exchange rate can strengthen or weaken the relationship of systematic risk to stock prices. The rupiah exchange rate can increase stock prices when systematic risk is high and can reduce stock prices when systematic risk is low. This indicates that the rise or fall in the value of the rupiah can moderate the relationship of systematic risk to stock prices and the rupiah exchange rate can also affect the stock price variable. directly because the exchange rate variable is a quasi-moderation variable where this variable can be a moderating variable as well as an independent variable on stock prices.

From the results of the study, it was found that the weakening of the value of the rupiah caused inflation in the country so that it encouraged an increase in systematic risk in the banking sector which made the expected return to rise. Rising returns encourage investors to invest. Directly the weakening of the exchange rate can directly affect the increase in stock prices because foreign investors consider that the price of shares offered is lower with the risks that must be borne by outside investors with domestic investors. In addition, the weakening of the rupiah exchange rate against the dollar has increased the demand for export of domestic products, which has increased the profitability of the company. This is consistent with the statement that the currency exchange rate is a macroeconomic variable predict changes in capital markets (stock prices) [1], [15], [3]. the results of these studies are also supported by research conducted which states that the value of currency mats and inflation can affect changes in stock prices [15].

The rupiah exchange rate against the US dollar can weaken the relationship of systematic risk to stock prices. So that the exchange rate can be used as a benchmark to be used as one of the factors that can affect stock price movements. This is because the exchange rate movement is not significant for three consecutive years during the research period changes in exchange rates are very small and can be said to be consistent. So that changes in the exchange rate can be used as a benchmark for investors to decide on investments that will be done or to maintain the investment that has been made.

\section{CONCLUSION}

Based on the results of the research and discussion, it can be concluded that the systematic risk represented by beta stocks can directly influence changes in stock prices. Because of the high systematic risk of a stock, the higher the price of the stock. Interest rates can strengthen the effect of systematic risk on stock prices and the relationship between interest rates and stock prices is negative so that if interest rates fall then the stock price will increase. Exchange rates cannot strengthen the effect of systematic risk on stock prices but instead weaken the effect of systematic risk on stock prices which means that the exchange rate cannot affect changes in stock prices.

\section{ACKNOWLEDGMENTS}

Our gratitude goes to the Dean of the Faculty of Economics, State Islamic University of Maulana Malik Ibrahim Malang who has provided us with research opportunities. And thank to the director of the Investment Gallery, Faculty of Economics, for the opportunity for us to do research in the investment gallery.

\section{REFERENCES}

[1] E. Tandelilin, Analisis Investasi dan Manajemen Portofolio, Yogyakarta: BPFE-Yogyakarta, 2001.

[2] A. Halim, Analisis Investasi, Jakarta: Salemba Empat, 2005.

[3] Kamaludin, Manajemen Keuangan Konsep Dasar dan Penerapannya. Bandung: CV Mandar Maju, 2011.

[4] J. Hartono, Teori Portofolio dan Analisis Investasi, edisi kesebelas, Yogyakarta: BPFE-Yogyakarta, 2017

[5] Y. A. Zaimur (translator), Dasar-Dasar Manajemen Keuangan Perusahaan (jilid 1), Jakarta. Erlangga, 2008

[6] E. F. Brigham, J. F. Huston, Fundamental of Financial Management, in D. Suharto, H. Wibowo, Manajemen Keuangan, Edisi 8, Jakarta: Erlangga, 2001

[7] S. Suspopranoto, Keuangan Perbankan dan Pasar Keuangan. Jakarta: Pustaka LP3ES Indonesia, 2004

[8] H. C. Berlianta, Mengenal Valuta Asing, Yogyakarta: Gadjah Mada University Press, 2006

[9] I. Putong, Pengantar Ekonomi Mikro dan Makro, Jakarta: Ghalia Indonesia, 2003 
[10] M. S. Yusi, Faktor Fundamental dan Risiko Sistematik Implikasinya terhadap Harga Saham, "Jurnal Keuangan dan Perbankan", 15(1) (2011) $40-48$.

[11] D. A. Rahmani, Pengaruh Faktor-Faktor Fundamental dan Risiko Sistematis Terhadap Harga Saham. Thesis. Sekolah Pasca Sarjana Universitas Pendidikan Indonesia, 2017

[12] F. Maulana, "Analisis Faktor Fundamental dan Risiko Sistematik Terhadap Harga Saham Perusahaan Sektor Property dan Real Estate di Bursa Efek Indonesia”, KINDAI, 13(2) (2017) $113-122$

[13] D. Retnaningsih, Analisis Pengaruh Risiko Sistematik dan Faktor Fundamental terhadap Harga
Saham Pada Perusahaan Keuangan Go Public di Bursa Efek Jakarta. Skripsi. Fakultas Ekonomi Manajemen Universitas Muhammadiyah Surakarta, 2017

[14] D. Andriana, Denny, "Pengaruh Nilai Tukar Terhadap Harga Saham Setelah Initial Public Offering (IPO)", Jurnal Riset Akuntansi Dan Keuangan, 3 (3) (2015) 761-767, DOI: https://doi.org/10.17509/jrak.v3i3.6619

[15] E. Saputra, B.H. Santoso "Pengaruh Nilai Tukar Mata Uang, Inflasi, dan Suku Bunga Terhadap Harga Saham Sektor Properti”, Jurnal Ilmu dan Riset Manajemen, 6(5) (2017) 1-16. 